\title{
INTERPOLATION POLYNOMIALS AND INEQUALITIES FOR CONVEX FUNCTIONS OF HIGHER ORDER
}

\author{
JosiP PEČARIĆ AND VERA ČULJAK
}

\begin{abstract}
In this paper we prove several inequalities for convex function of a higher order. Generalizations of Hadamard's inequalities and the conversion of Jensen's inequality for $(n)-$ convex function and with conditions on the regular, real (signed) Borel measure are presented by Lidstone's and Hermite's interpolating polynomials. As a discrete form we also obtain a generalization of Perovič's inequality, i.e. Giaccardi's inequality. The Abel-Gontscharoff interpolating polynomial with two-point right focal conditions leads us to an inequality like converse of Jensen inequality for a regular, signed measure and, as a consequence, to some inequalities related with Hadamard's and Petrović's inequalities.
\end{abstract}

Mathematics subject classification (2000): 26D07, 26D15, $26 \mathrm{~A} 51$.

Key words and phrases: Jensen inequality, Hadamard inequality, Petrović inequality, Giaccardi's inequality, Lidstone polynomial, Hermite interpolating polynomial, Abel-Gontscharoff interpolating polynomial, $(n)$ - convex function.

\section{REFERENCES}

[1] J. E. PEČARIĆ AND P. R. BEESACK, On Knopp's inequality for convex functions, Canad. Math. Bull., Vol. 30 (3), (1987), 267-272.

[2] P. R. BEESACK, On inequalities complementary to Jensen's Can. J. Math. 35 (1983), 324-338.

[3] J. E. PeČARIĆ, F. Proschan AND Y. L. TONG, Convex functions, partial orderings, and statistical applications, Academic Press,Inc, Boston/ London, 1992.

[4] A. M. FInK, A best possible Hadamard inequality, Math. Inequal. and Appl., Vol. 1 (2), (1998), 223-234.

[5] G. J. LIDSTONE, Notes on the extension of Aitken's theorem (for polynomial interpolation) to the Everett types, Proc. Edinburgh Math. Soc. (2), 2 (1929), 16-19.

[6] D. V. WIDDER, Completly convex function and Lidstone series, Trans. Am. math. soc., 51 (1942), 387-398.

[7] R. P. Agarwal, P. J. Y. Wong, Error Inequalities in Polynomial Interpolation and Their Applications, Kluwer Academic Publishers. Dordrecht / Boston / London, 1993.

[8] J. M. WhitTAKER, On Lidstone series and two-point expansions of analytic functions, Proc. Lond. Math. Soc., 36, (1933-1934) 451-469.

[9] J. E. PEČARIĆ, AND V. ČULJAK, Inequality of Petrović and Giaccardi for convex function of higher order, Southeast Asian Bulletin of Mathematics, submited for publication.

[10] T.Popoviciu, Sur l'approximation des fonctions convexes d'ordre superieur, Mathematica 10, (1934), $49-54$.

[11] D. S. Mitrinović, J. E. PeČARIĆ, On some applications of Hermite's interpolation polynomial and some related results Symposium Num. Meth. Appr. Th. Niš. (1984), 93-98.

[12] D. S. MitRINOviĆ, J. E. PEČARIĆ, A. M. FINK, Inequalities involving functions and their integrals and derivatives, Kluwer Academic Publishers, Dordrecht / Boston / London, 1991.

[13] L. FeJER, Uber die Fouriereichen II, Gesammelte Arbeiten I (German) Budapest (1970).

[14] I. S. Berezin, N. P. Zhidkov, Computing Methods, Pergamon Press, Oxford, 1965.

[15] S. KarLin, Total Positivity, Stanford Univ. Press, Stanford, 1968. 
[16] S. KARLIN, W. J. STUDDEN, Tchebycheff systems: with applications in analysis and statistics, Interscience, New York, 1966.

[17] A. JU LEVIN, Some problems bearing on the oscillation of solutions of linear differential equations, Soviet Math. Dokl. 4 (1963), 121-124.

[18] P. R. BEESACK, On the Green's function of an N-point boundary value problem, Pacific J. Math. 12 (1962), 801-812.

[19] F. GIACCARDI, Su alcune disuguaglianze, Giorn. Mat. Finanz. 1 (4) (1953), 139-153.

[20] M. Petrović, Sur une functionnelle, Publ. Math. Univ. Belgrade 1 (1932), 149-156.

[21] J. E. PeČARIĆ, V. ČULJAK, A. M. FINK, On some inequalities for convex function of higher order, Nonlinear studies, vol. 6, No. 2. (1999), 131-140.

[22] J. PEČARIĆ, V. ČULJAK, M. RoGINA, On some inequalities for convex function of higher order, Nonlinear Analysis-Theory methods and Applications, 45 (2001), 281-294. 